\title{
The unit of resilience: unbeckoned degrowth and the politics of (post)development in Peru and the Maldives
}

\author{
Eric Hirsch ${ }^{1}$ \\ McGill University, Canada
}

\begin{abstract}
This article asks how people envision lives without economic growth in contexts where conventional development ceases to be feasible. It presents ethnographic research I conducted in Peru and in the Maldives, which policymakers see as two climate crisis frontiers. I argue for defining resilience as a grounded, necessarily local, actor's theory of permanence; it is a theory people from diverse social classes and institutions generate in situations of vulnerability and crisis. In the Andes' Colca Valley, which some residents predict has only several habitable decades left due to increasing water scarcity, sustainable development projects are attenuating their presence as their budgets shrink, while mining enterprises and their corporate social responsibility programs have emerged as development's new agenda setters. The Maldives is one of the world's lowest-lying nations, which rising seas could soon render uninhabitable. Between 2008 and 2012, President Mohamed Nasheed made addressing the climate crisis a policy priority by substituting conventional industrial development with a short-lived quest for national carbon neutrality. Examining this contrapuntal pair of frontier sites, I argue that defining the unit of resilience is a political act: forging this definition means prioritizing what, in a human-driven ecosystem, should remain permanent and what should be left behind.
\end{abstract}

Keywords: resilience, degrowth, climate change, Peru, Maldives

\section{Résumé}

Cet article interroge comment des personnes envisagent une vie sans croissance économique dans des contextes où le développement conventionnel cesse d'être faisable. Ceci présente des recherches ethnographiques menées au Pérou et aux Maldives, que les décideurs politiques considèrent comme deux frontières de crise climatique. Je soutiens qu'il faut définir la résilience comme une théorie qui est mise à la terre, nécessairement locale, et basé sur l'acteur; c'est une théorie de personnes qui viennent de diverses classes et institutions sociales et qui se génèrent en situation de vulnérabilité et de crise. Dans de la vallée du Colca aux Andes, où certains résidents présagent que celle-ci a seulement quelques décennies habitables à cause du manque d'eau, les projets de développement durable atténuent leur présence tandis que leurs budgets rétrécissent. De plus, les entreprises minières et leurs programmes de responsabilité sociale sont considérés comme des fixateurs de nouveaux programmes de développement. Les Maldives est une des nations ayant l'altitude plus basse au monde, qui à cause de la montée des mers pourraient bientôt rendre inhabitable. Entre 2008 et 2012, le président Mohamed Nasheed décréta la crise climatique une priorité politique en substituant le développement industriel avec une quête de courte durée qui prévoyait atteindre une empreinte de carbone neutre. En faisant l'examen de deux sites frontaliers, ceux-là permettent un contrepoint d'où je soutiens que la définition de l'unité de la résilience est un acte politique: forgeant cette

\footnotetext{
${ }^{1}$ Dr. Eric Hirsch, Postdoctoral Fellow, Institute for the Study of International Development, McGill University, Montreal, Canada. Email: eric.hirsch "at" mcgill.ca. I would like to acknowledge the staff of the Desco NGO in Lima, Arequipa, and Colca, Peru, the Andean Studies Program of the Pontificia Universidad Católica del Perú, and the Bluepeace Maldives NGO. Profound thanks to Lisa Gezon, Susan Paulson, and the other helpful members of the "Culture, Power, Degrowth" group, who heard and read earlier iterations of this article. Field research for this article was supported by the Fulbright-Hays fellowship, the Wenner-Gren Foundation, the Inter-American Foundation, the Institute for Money, Technology, and Financial Inclusion at the University of California-Irvine, the Social Science Research Council, a Foreign Language and Area Studies fellowship for Quechua, and the University of Chicago's Department of Anthropology and Center for Latin American Studies. This is the second article in Lisa L. Gezon and Susan Paulson (eds.) 2017. "Degrowth, culture and power", Special Section of the Journal of Political Ecology, 24: 425-666.
} 
définition signifie prioriser ce qui, dans un écosystème entraîné par l'être humain, doit rester permanent et ce qui devrait être laissé de côté.

Mots-clés: resilience, décroissance, changement climatique, Pérou, Maldives

\section{Resumen}

En este artículo se pregunta cómo la gente se imagina la vida sin crecimiento económico en contextos en desarrollo convencional deja de ser factible. Se presenta una investigación etnográfica que realicé en Perú y en las Maldivas, que los políticos ven como dos fronteras crisis climática. Yo argumento para definir la resistencia como a tierra, necesariamente locales, la teoría del actor de la permanencia; se trata de una teoría de personas de diversas clases sociales y las instituciones generan en situaciones de vulnerabilidad y crisis. En los Andes 'Valle del Colca, que algunos residentes predecir sólo tiene varias décadas habitables izquierdo debido a la creciente escasez de agua, proyectos de desarrollo sostenible están atenuando su presencia como sus presupuestos se reducen, mientras que las empresas mineras y sus programas de responsabilidad social de las empresas se han convertido en la nueva agenda de desarrollo definidores. Las Maldivas es uno de los países situados a menor altura del mundo, que el aumento de los mares podrían pronto rinda inhabitable. Entre 2008 y 2012, el presidente Mohamed Nasheed hizo frente a la crisis climática una prioridad política mediante la sustitución de desarrollo industrial convencional con una misión de corta duración por la neutralidad de carbono nacional. El examen de este par de contrapunto de los sitios fronterizos, se argumenta que la definición de la unidad de la resiliencia es un acto político: la forja de esta definición significa dar prioridad a lo que, en un ecosistema inducido por el hombre, debe seguir siendo permanente y lo que se debe dejar atrás.

Palabras clave: la capacidad de recuperación, decrecimiento, cambio climático, Perú, Maldivas

\section{Introduction}

Peru and the Maldives offer politically potent images of climate crisis. In Peru, Andean peaks are turning from white to brown. Glacial retreat is upending existing irrigation systems in the Andes' mountain communities. As Andean glaciers melt, the level of the Indian Ocean rises on the other side of the world. Many of the sea level rise scenarios for the year 2100 could mean that the low-lying Maldives cease to be habitable, as its small islands at elevations no greater than $2 \mathrm{~m}$ transform from green to blue. It is difficult to predict exactly how climate change's consequences will unfold (Webb and Kench 2010). But state and civil society institutions in both places have seized on these reproducible images of climate crisis to motivate adaptive change, and also to imagine the ways it might be possible to stave off change, at multiple scales.

This article is about the politics of scale emerging through that negotiation in Andean Peru and the Maldives, two sites widely considered to be frontiers for climate change (Altamirano 2014; McKibben 2010; Postigo 2014; Warner et al. 2012). I investigate the ways people experience and theorize resilience. This is an analytical term I define as the negotiated compromise between adaptation and resistance to fundamental change. Doing so, I suggest, is a political act. How do people living in these frontier spaces imagine their own resilience, and that of their environments and economies, after conventional forms of development cease to be feasible? How are decisions about the future - made in the face of climate change - geophysically and geopolitically connecting receding glaciers with rising seas?

Andeans and Maldivians seem to be experiencing the opposite ends of a single crisis: the Andean mountain range faces water scarcity and crop death due to melting glaciers and disappearing snowpack, while the low-lying small islands of the Maldives face a rising Indian Ocean whose inundation could render it completely uninhabitable by 2100. At the same time, pairing these two places yields contrapuntal development policy shifts: while the Andes have seen a turn away from sustainability interventions in recent years, the Maldives was embracing them. Mitlin, Hickey, and Bebbington distinguish two types of development at issue into development as an ongoing process and development as an active project (2007; see also the introduction to this Special Section, Paulson 2017). They describe economic development-a measure of the everyday growth and circulation of things of value—as "lowercase $d "$ development (2007). They label formal development interventions as "uppercase D" development. In this article, I interrogate the opposing shifts between development and Development that climate change is conditioning. 
The Andes' Colca Valley is a small network of communities in southern Peru that since the late-1960s administration of Juan Velasco Alvarado has received some attention as a site of modernization interventions, such as using fertilizers to increase agricultural yield. The 1990s saw the paving of a highway between the nearby city of Arequipa and Colca, and the expansion of the electric and hydraulic grids to the region's homes. Since then, Colca has been a site in which large-scale modernizing projects started to wane. Shrinking national infrastructure support and service provision gave way after 2000 to small-scale NGO projects focused on sustainable entrepreneurship, one of which I detail below. In light of the simultaneous frontier push by mining enterprises into Colca and the surrounding Caylloma Province, the region is now seeing the closure of those small-scale initiatives, shifting toward emissions-intensive development by capitalizing on Peru's frontier push to extract mineral wealth.

In the Maldives' recent history, by contrast, the 2008-2012 administration of former president Mohamed Nasheed made the controversial decision to completely shift the country away from conventional industrial development. They set an unprecedented national goal: to become the world's first carbon-neutral country by the year 2020. This national-level degrowth, like many of the intentional projects detailed in this Special Section (Paulson 2017; Berglund 2017; Lockyer 2017; McGuirk 2017), raised internal questions about what it might mean to turn away from carbon-intensive development in a staple goods-stressed economy whose carbon footprint was effectively negligible.

As both places face these changes, I suggest using ethnography to provide a nuanced political reading of what it means to be resilient. Resilience, I argue, is best understood analytically as a grounded, actor's theory of permanence. Determining the object or category meant to be permanent, which I call the unit of resilience, is an important decision about scale and sociality: this unit can be a place, a community, an ecosystem, a market, a practice, an individual, or a nation-state, for instance. ${ }^{2}$ My ethnographic data from Peru and the Maldives illustrate that institutional actors leading formal interventions rooted in reducing certain kinds of growth, and whose philosophies converged with the basic ideas of degrowth, saw resilience as part of the process of making a place or practice sustainable. The people they intended to benefit, by contrast, took resilience outside of the realm of ecologically conscious survival, and often saw growth, urbanization, and even mineral extraction as forms of resilience. I therefore also argue that defining the unit of resilience is a political act, for it is a means of prioritizing what, in a human-driven ecosystem, should remain permanent.

Resilience has had many definitions in a long history dating back to its Latin roots. It principally referred to some variation on the idea of "bouncing back" until the twentieth century, when the idea of "ductility had been added to elasticity" (Alexander 2013); recently, it has become an organizing term for describing responses to contemporary ecological crises. Crawford Stanley Holling offered a foundational definition in 1973 for contemporary understandings of resilience in ecological science: "a measure of the persistence of systems and of their ability to absorb change and disturbance and still maintain the same relationships between populations or state variables" (1973; cited in Alexander 2013). More recently, Alexander glosses Holling's definition as the idea of absorbing "shocks without major loss of form and function" (2013). One of its simpler scholarly definitions today, from anthropologist of climate change and migration Susan Crate, is "adaptive success" (2011: 180). Another, from Heather Lazrus, is "the ability to absorb or recover from exposure to stresses" (2012: 286).

All of these definitions give resilience the social purchase to signify a local response to sudden or rapid change. But as political ecologists have frequently noted with other broad and positive terms emerging from environmentalist movements such as "sustainability," the notion of resilience is malleable enough to be "wide open for political and social manipulation" (Anderson 2015: 240). Thus, my contribution to political ecology ports the field's concern with critiquing the dynamics of power, politics, uneven access to resources, and structural inequality at multiple scales of the world's ecology (Paulson 2014; Peet, Robbins and Watts 2011; Watts and Peet 2004) into these frontier sites of climate change in order to dissect conflicting images of human permanence. The concept of resilience as I see it emerging in Peru and the Maldives opens an ecological politics which suggests that a community's aggregate strength in the face of climate change's

\footnotetext{
${ }^{2}$ This idea was inspired by Schuster's notion of the "social unit of debt" (2015).
} 
multivalent challenges depends partly on its ability to prioritize certain features of collective life as features that ought to endure, which is political in that it can mean deciding to discard other values deemed less important to a shared long-term future. Here, I analyze the way resilience is theorized and contested on the ground in institutions devoted in practice (if not necessarily in name) to principles of degrowth, and by the people that those projects are attempting to render resilient.

Both places exemplify an additional global trend. The flow of international, state, and civil society aid investments in the name of establishing endogenous growth has decreased dramatically, marking a possible end to development intervention as these places know it. This means that Andean Peru and the islands of the Maldives are seeing a partly chosen, and partly forced, downshift in both intervention-based "D" development and economic growth that make them, in distinct ways, sites of policy paradigm change, and therefore fertile places for an ethnographic analysis of what "postdevelopment" life might look like (Escobar 1995). This article tracks the way concepts of permanence are forged along development's downward shifting gradient. To some I interviewed in this multi-sited comparison of highlands and islands, the closing of civil society interventions released dependency's grip. To others, the end of conventional aid was a signal of state disinvestment.

The way people, institutions, and polities render meaningful the malleable idea of resilience has a great deal to tell us about what Demaría et al. (2013: 208) call "the political subject of degrowth." What does this political subject look like? Degrowth-for whom?

Inhabitants in both places have been forced to weigh uncomfortable choices to adapt to these climatic and policy changes. I suggest that as inhabitants make negotiations between different forms of economic and ecological life, they are debating not whether to become resilient, but how to be so. That means asking: What aspects of life, community, and ecology are meant to endure in the face of vulnerability? Does resilience mean the ability to stay in place, despite the difficulties of doing so? Or is it best understood as the ability to leave?

To answer these questions, I draw on two years' total of ethnographic research in Andean Peru's Colca Valley conducted longitudinally between 2008 and 2016, where I engaged in participant-observation, conducted over 100 semi-structured interviews and life histories, and worked with a cross-section of civil society organizations and families. I also draw on a briefer period of research in the Maldives, where I spent six weeks in 2011 and have been engaging with my interlocutors and following political and social movements there remotely since 2009. While there, my participant-observation centered on the Bluepeace Maldives NGO and semi-structured interviews throughout the capital city of Malé.

In what follows, I first contextualize degrowth and emerging concepts of resilience in the scholarly literature, and point out the puzzling ways the degrowth emphasis on smallness converges with the global wave of neoliberal disinvestment. I suggest that the people who become the objects of resilience projects must negotiate how to flourish in policy contexts where degrowth and disinvestment are sometimes indistinguishable. I then discuss the work of two NGOs and their intended community of participants: Desco (the Center for the Study and Promotion of Development) in Peru, and Bluepeace in the Maldives. The conclusion turns to a broader discussion of what it means to imagine permanent life from the standpoint of shifting regimes of $\mathrm{D} /$ development at the frontiers of climate crisis.

\section{Facing change: degrowth and disinvestment}

The "degrowth" project is a heterogeneous grouping of ideas with certain key patterns and conceptual foundations. We may define it for the purposes of this article as a set of values and a social movement that advocates scaling down economic activity so that it ceases to overwhelm "the carrying capacity of the biosphere" (Whitehead 2013: 142). This is a largely Euro-American iteration of similar ideas about living healthfully and happily expressed in the Buen Vivir, Swaraj, and many other ecological-economic downshifting movements. It emerges as a reaction to "failures of the growth paradigm," broadly calling for the repayment of a "vast and rapidly growing ecological debt" (Kosoy et al. 2012: 74). According to Serge Latouche's seminal description (2009), key to this movement is a focus on the values of justly distributed wealth. In one criticism of the concept, Brian Gilmore argues that Degrowth presents a conundrum with respect to the global south: it is ethically flawed, he suggests, to convince "developing nations that they 
should halt or significantly alter their economic development and growth and not seek to change the standard of living" (Gilmore 2013: 1284).

For the purposes of this article, I will not offer a definitive evaluation of this concept's merits, but rather, observe how it works in practice. One important factor that complicates these principals is their convergence with a scarcity forced by state disinvestment from marginalized communities around the world. Given this process, we can draw another "d" versus "D" distinction for the term "degrowth." Uppercase Degrowth is an activist project that aims toward smaller economies and that converged with NGO staff ideas in Peru and the Maldives. I use the lowercase degrowth, on the other hand, to refer to the broader process of growing smaller and consuming less. To many non-elites I met during my fieldwork, disinvestment and unbeckoned degrowth were indistinguishable.

Although Degrowth is ideally part of a broader redistributive and non-capitalist project (Boonstra and Joosse 2013), the two ethnographic sites examined below offer images of degrowth without equitable redistribution because of the limits imposed by the current economic order, which tends to result in the augmentation of inequality and the redistribution of wealth to the hands of the few. Tracking these convergences is essential for understanding how D/degrowth functions in the particular sites in which dimensions of the movement's philosophies are implemented. If the ideas it entails inspires some development workers, degrowth is also a strategic choice, for the practitioners I observed must intervene with only a small project-based budget that helps render disinvestment palpable through an emphasis on capacity building and local self-reliance. Indeed, the language of self-driven empowerment and entrepreneurship (Brown 2015; Cruikshank 1999) populating official NGO language can be strikingly similar to Degrowth language espousing smallness (McKibben 2010; Whitehead 2013).

Many scholars of economic life today particularly emphasize contemporary market capitalism' voracious capacity to "coloniz[e] the field of value-reducing all social values to one market valueexhausting alternative social projects by denying them sustenance" (Povinelli 2011: 134; see also Brown 2015). Degrowth and its related ideas have gained influence as a form of resisting that voraciousness (McKibben 2010) and even in bodies like the UN (see epigraph to Kosoy et al. 2012). Observing how that influence works in practice is a key focus of this article and something which contributors to this special issue share (see Lockyer 2017; Verma 2017; and DeVore 2017 in this volume). As the next two sections argue, the imposed requirement to get by on fewer resources resulting from the strange convergence of disinvestment and degrowth can be both emancipatory and oppressive. Failing to link economic downshifting to adequate structures of redistribution can decouple everyday resilience from care for the earth.

\section{Andean Peru: a forced degrowth?}

The ecological scarcity that climate change is bringing about with unprecedented force places the people of the Andes' Colca Valley at a crossroads between finding ways to survive in the existing economy and significantly changing their life endeavors. Either path can be read as a resilient choice. The key distinction between them is the unit of resilience. My investigation of the Desco NGO's interventions in Colca and of the region's changing agricultural and market economies revealed that this unit shifted, depending on priorities for what aspect of life needed to endure. This ethnography examines several different units and their relationships to the future, including: region (the Colca Valley); family; community/collective; individual (i.e. an entrepreneur); cultural or ethnic group; institution; Andean ecosystem.

The Colca Valley region has seen dramatic shifts in the agricultural calendar that have largely resulted from climate change. An increasing number of young people have migrated to Arequipa, Peru's second mostpopulous city some 150 kilometers away from Colca, and to other urban centers. Many more Colcans leave the formerly predominantly agricultural region to pursue labor opportunities in other places, as a oncebooming subsistence and cash-crop agricultural economy in Colca occupies fewer livelihoods. Leaving agriculture is a resilient move to some (Checca interview 2015); to others, this means giving up something fundamental (Huaracha interview 2014).

In the Andes, sophisticated water use regimes have long operated and evolved to manage water as a common good (Postigo 2014). Water politics have long been elaborate and rich with tradition, and also, tense and difficult. This is due to the delicate challenge of utilizing limited sources in terrains immensely 
variegated in their altitudes (Gelles 2000). One of the most important biophysical transformations achieved by pre-Inca societies and the Inca empire was an approach to irrigation that used gravity and collaborative social responsibility to bring water through canal systems from glaciers and snowcapped peaks to crop areas differentiated by altitude. Spanish colonists attempted to consolidate the Andean population into large, dense towns, called reducciones, which for Colca put a strain on those delicate water-sharing arrangements, in which human settlement was often conditioned by water access (Mumford 2012).

Such structural strain has persisted for many of Colca's village water systems through the present (Hirsch 2016). Its current convergence with climate change amounts to a perfect storm of resource scarcity that causes Colcans to predict that their land will cease to be habitable within decades (Checca interview 2015). Glacial retreat and decreased mountain snow cover are putting new pressures on communities dealing with both state disinvestment and ecological change (Bolin 2009; Carey 2014; Postigo 2014). During my time living in and visiting the Colca village of Yanque between 2008 and 2016, water scarcity became a matter of increasing daily importance. Residents like the 78-year-old Don Gerardo Huaracha have been watching the peaks of three local mountain deities, Mismi, Ampato, and Hualca Hualca, lose their snow. ${ }^{3}$ Huaracha has been an attentive participant at the monthly meetings of the local water commission, where he was once president. This is a body in charge of regulating access to communal irrigation, assigning farmers to regularly scheduled obligatory work parties, and levying water taxes (Huaracha interview 2014). Its meetings have recently become panicked affairs.

According to Huaracha and his 82-year-old wife Luisa Cutipa, harvests have also become worse. Despite this, their version of resilience was staying in their homes. They live by farming, caring for animals, and benefiting from remittances from family members who have migrated to cities throughout Peru. Such a choice suggests a kin-based extension of Murra's "vertical archipelago" model: part of this household's resilience is to remain in place even in a poor harvest period by drawing on a family network diversely situated in Peru's nationally structured hierarchy of resource access (Murra 1972). The elderly couple did not use the term "resilience" explicitly, as did certain younger adults who had interacted with the region's Arequipa-based NGOs, but they framed staying as a value. Indeed, staying was the only feasible option for them, as it was for many in their generation who shared place-based intersectional identities, and had land in active use, animals in their care, homes they had built and rebuilt for years, property, advanced age, and a closely knit kinship network that put migration beyond the realm of possibility.

The increasing scarcity of water that glacial retreat has brought about emerged with a package of other alarming changes. In 2013-2014, the rainy season began two months late, resulting in a drought from December 2013 to March 2014 that made the land inhospitable for planting. Rain in March, April, and May was once rare, even when I started my visits in 2008. But after March 2014, rain arrived in the form of dangerous downpours, intense thunderstorms, and baseball-sized hail, destroying a substantial number of the crops that managed to survive the drought. While development specialists lamented the tendency for young people to migrate to nearby cities like Arequipa, this was not simply because farming has fallen out of fashion. Agriculture in much of the valley has ceased to be feasible.

When I arrived to Yanque for extended field research in 2013, I learned that the nearby volcano Sabancaya had become active. It was causing the occasional tremor and warnings of a more significant earthquake. Rolando Checca, another Yanque resident, warned in October 2013 that a sufficiently strong quake would break one of the valley's large manmade backup reservoirs, potentially destroying Yanque and its neighboring villages. I asked about this potential flood some six months later, upon which he indicated that the reservoir was now almost empty, and that Colca would not be destroyed by flood but by drought: it was quite possible, Checca said, that in ten years the Colca Valley would cease to be habitable. So, the mountains surrounding this basin of human settlement have become constant reminders of the changes that threaten the ability to survive and to thrive. Apus were long the objects of worship, indicating a profound respect for the majestic surrounding land, in part because their snowpack was a key water source. Mountains

\footnotetext{
${ }^{3}$ See De la Cadena (2015) for a discussion of the spirituality of mountain deities and, more generally, Andean tirakuna or "earth-beings."
} 
covered in snow feature heavily in rituals asking for water. Today, their snowless peaks continue to inspire respect, but they are also new reminders of fragility.

This is the ecological context in which NGO-based development projects have come to intervene. In Peru, as in much of the world, contemporary development interventions mean small, restrained, highly focused interventions, on tight budgets, that ask participants to draw upon their own economic resources and social capital (Rudnyckyj and Schwittay 2014; Elyachar 2005; Mosse 2013). In Colca, these projects were funded by state initiatives such as Fondoempleo (the National Fund for Labor Capacity Building and Employment Promotion), and international aid programs such as the Spanish Agency for International Development Cooperation. Thus, through its reduction in scope, the development sector has undergone its own effective degrowth at both national and international scales. While the environmentalism of the staff in NGOs such as Desco did not tend to be explicitly affiliated with any movement, many were interested in researching and implementing new practical ways to sustain locally oriented economic life, which they also saw as interventions that would fit their increasingly tight budget constraints.

Technocratic ideas of environmental stewardship promulgated by development agents (Dapino interview 2014; Suni interview 2014) helped to construct a local development paradigm centered on cultivating resilient, place-based entrepreneurship that would help "revalorize" Colca's indigenous traditions. Desco's institutional argument was that instead of investing in massive infrastructure and construction projects, to then leave in its wake what one activist writer called the "garbage of development" (Grillo Fernandez 1998), NGO programs can, with smaller investments, build in its participants the creative capacity and business savvy needed to create lasting economic and ecological resilience (Llosa et al. 2011; Poma interview 2014).

Desco defines "resilience" as simply "adaptation" (Llosa et al. 2009: 24). Adaptation, for this NGO, ranged from restoring traditional land use techniques such as terraced farming to increasing opportunities for employment. One of Desco's projects from the mid-2000s was explicitly oriented by what Colca Director Delmy Poma called the institution's "transversal theme" of strengthening cultural identity and local resilience (interview 2014). It entailed restoring Andean terraces, a historic technology that enabled peasants to farm a diversity of crops at different elevations (see Murra 1972). Terraces are prominent features of Colca's vast pre-Inca landscape, and also key to Colca's emergence as a tourist attraction over the past twenty years. On one stone wall that formed part of a terrace Desco staff restored with the help of local laborers, the NGO left its signature in crisp white paint. Some ten years later, the now-faint letters of Desco's signature have been overtaken with creeping plants and vegetation, with these terraces now a ruin of ruins restored. Terraces were imagined as permanent features of the agricultural economy, and are still used in certain parts of the valley. However, their role as an indigenous strategy for ensuring permanence has faded given the trend of diminishing agricultural yields as a reliable source of sustenance.

Desco's more recent projects deliberately shifted the institution's unit of resilience from agricultural terrain to individual human entrepreneurs. From 2013 to 2014, Desco ran an eighteen-month project in which it awarded fifty young entrepreneurs investments of seed capital, training, and discounted access to microcredit. This was an attempt to incentivize residents to remain in Colca's communities instead of migrating to Arequipa. The NGO's vision was to create a series of enduring sustainable businesses, which in turn were imagined to stimulate the local economy and thereby eliminate inequality via the market. Despite Desco's devotion to fair and ecologically conscious degrowth, its job creation framework rendered endogenous growth the only feasible form of effectively redistributing resources, with the proliferation of employment and local expertise in small-scale sustainable jobs framed as both economic and ecological resilience.

Crafting economically and culturally resilient entrepreneurs who would in turn create jobs was the best way NGO workers like Fabiola Dapino and Delmy Poma saw to secure funding from the agencies responsible for keeping the Desco office running. Resilience here opened a form of conceptualizing a Quechua language-speaking Collagua and Cabana indigenous person ${ }^{4}$ as a category that can accommodate change, but that also has sufficient integrity to have endured brutal colonization. These interventions rely on

\footnotetext{
${ }^{4}$ The Collaguas and the Cabanas are the groups that have historically populated the Colca Valley's villages.
} 
the idea that each business puts Andean indigeneity to work. One young entrepreneur, Rogelio Taco, used his seed capital to build a guinea pig barn, and with Desco's help became one of the highest-selling guinea pig vendors in the entire province. Taco's success reaping high returns from almost zero monetary support exemplified development's financialization; in our interview, he explicitly described the purchase of a guinea pig as an investment. Other entrepreneurs offered tourism services, construction, and gastronomy, with varying degrees of success. Overall, they saw mixed results: there were a number of success stories like Taco's. Dapino, Desco's specialist in entrepreneurship capacity building, suggested it was only likely that a low percentage of participants would be able to transform their seed capital into a thriving business that turns a profit. Others quickly abandoned their businesses. Several of the fifty winners ended up moving to Arequipa, an alleged uprooting (but in practice, not that at all-see Murra 1972) that the NGO saw as disqualifying.

Indigeneity helped NGO workers imagine their individual units of resilience. The idea of being indigenous, for Desco, went beyond something that can simply be used to help promote and market an entrepreneur's good or service. More than just a commodifiable subject of "ethno-development" (Andolina et al. 2009; Comaroff and Comaroff 2009), indigeneity took the form of what Peter Galison has called a "theory machine" (Galison 2003) for building concepts of permanence in the Colca Valley. It structures ideas of a resilient, locally rooted life in social, economic, metabolic, and environmental equilibrium. Indigeneity grounds the idea of an economic and ecological system that can last in the face of devastating odds, fitting the textbook definitions of resilience discussed above. Desco's institutional logic suggests that an unvanquished Colcan indigeneity was always there and, with these projects' help, always will be.

But development institutions were closing their intervention programs as of late 2014, terminating or attenuating their presence. Funding cycles came to an end for Desco's youth entrepreneurship project. As director Delmy Poma of Desco's Colca office told me, it had become increasingly difficult for the NGO to win the competitive funding necessary to start new local intervention projects. This was, in part, a forced degrowth of the development intervention field due to cutbacks in Peru's economic inclusion efforts, its state decentralization, and its current wave of disinvestment from rural communities, especially those registering lower extreme poverty indicators (Fuentes 2011).

Beyond the space of the development institution, and especially after the local diminution of intervention projects, many current and former Colcan agricultural workers were conceptualizing their own forms and units of resilience. The degrowth in Colca's development NGO presence has coincided with the growth of mining companies and their attached community foundations, which have taken center stage as core supporters of community life and even community identity through their corporate social responsibility agendas. Many males I met in Yanque across the class spectrum between the ages of twenty-five and fortyfive spent at least some time working in the mines, several of which are situated at Colca's edges. Gold, silver, and copper mining in Peru's Andes has helped to drive the country's high rate of annual economic growth over the past several years. Freddy Panuera, a Yanque-based veterinarian, regularly makes the thirteen-hour commute to his job at the Tintaya Foundation, the Tintaya mine's corporate social responsibility arm. He lives near the mine for nine-day cycles, and then gets to return home to Yanque for five days. Alan Huaracha, Gerardo and Luisa's youngest son, had worked as a manual laborer at that mine, and would frequently describe it as a lucrative employment opportunity.

For Colcans, mining jobs do tend to pay better salaries than more temporary and local forms of manual labor, such as short-term construction projects and archeological preservation work. Many nearby communities have protested mining enterprises and their sites, such as in Cocachacra in the province of Islay, west of Arequipa, where the Mexican Southern Copper Corporation has been unable to begin excavations in its Tía María mine site. There also exists an ongoing national concern among policymakers, in Colca and (as a more rampant problem) in the rest of the country, with the proliferation of smaller-scale artisanal mining. Many unregulated "artisanal" miners engage in many forms of exploitative activity, ranging from unsafe labor conditions to human trafficking to the invasion of terrains of environmental or traditional value (Bury and Kolff 2002).

However, mining is not simply a source of vice, crime, and human and ecological destruction. Rather, the people who work at formal and informal mines that I interviewed were deeply ambivalent about the 
consequences of extraction. Work in the mining industry offers laborers dreams of social mobility and independence. It is also sometimes the only employment option. As I describe elsewhere (Hirsch in press), setting up an informal mine was one family's entrepreneurship strategy, engaged as a last-resort effort to fight the joblessness and agricultural failure they increasingly had to endure. From technicians in the service of a CSR program like Freddy to day laborers such as Alan, Colcans widely consider work with a mining company as a pathway to economic stability. Many lower-level laborers saw the relatively high wages as outweighing the risks and dangerous conditions they would face as they handled machines, exposed themselves to various atmospheric and aquatic contaminants, and tunneled into the earth.

Colcans consistently indicated to me that the expanding mines were problematic and promising, given that usurpation of land and contributions to climate change came with pledges of employment and redistributed wealth. Labor in the mines crossed class lines. Its popularity, even among self-described environmentalists, suggested that resilience entails making often agonizing decisions about whether permanence will mean an economic endurance-bringing home enough money to put food on the table-or acting in other ways that ensure the community's ecological survival. Mineral extraction's expansion can also mean programs and subsidies meant to benefit continued peasant agriculture, a contradiction suggesting that the permanence of ecological life in one place can be the result of its destruction in another. While these categories are by no means neatly distinguishable, Colcan actors and collectives defined what resilience meant to them by defining its units: for example, the economic unit of the household, tourism sector, or gastronomy market, or the ecological unit of the watershed or pastureland.

This makes clear that choices about the unit of resilience directly shape the way resilience comes to matter. As the institutions capturing political power in the Colca Valley change from municipalities and NGOs to mining companies, rescaling the unit from an individual entrepreneur to a community to a household allows different kinds of choices to become ethical priorities. This rescaling is both spatial and temporal: the urgency of getting by in a day-to-day sense can render the "slow violence" of ecological and pulmonary destruction (Nixon 2011) irrelevant to the ordinary thriving of a family.

\section{The Maldives: reimagining the unit of resilience}

Compared to the Colca Valley, the Maldives has a distinct relationship to resilience. In this section, I analyze the three units of resilience that emerged during a particular Maldivian political moment: the world, the nation-state, and the individual.

The Maldives is one of the world's lowest-lying nations in the world. Rising seas may render it entirely uninhabitable by 2100. It is, in this way, a frontier of climate crisis. Between 2008 and 2012, the Maldives was subject to a new president's plan for it to become the world's first completely carbon-neutral country. I conducted ethnographic fieldwork there in 2011 as the plan began to took hold, framing the entire nation as the unit of resilience. Upon Mohamed Nasheed's unprecedented ascent as the country's first democratically elected president in three decades, addressing climate crisis quickly became one of his administration's most important priorities. He placed the Maldives under the global media spotlight when he held a SCUBA-aided cabinet meeting underwater to call attention to the country's vulnerability several months in advance of the 2009 Copenhagen climate conference.

Nasheed spent a great deal of political capital mobilizing on the international stage for greenhouse gas mitigation at the global scale, while devoting resources and cultivating grassroots energy for carbon neutrality at home. Here, the world became a distinct unit of resilience. Nasheed's administration and environmentalist supporters saw both as necessary for contributing to the global degrowth needed for the Maldives to survive as a nation. Key to this mobilization was a political and philosophical maneuver that entailed reworking the assumption that a nation's development has to do with carbon-dioxide emissions: as he would proclaim in speeches, "We want development, not carbon!"

In 2011 I followed the work of Bluepeace Maldives, the country's oldest environmental NGO. Bluepeace is an independent Maldivian organization whose mission is "to protect the environment through...education and training," "to increase awareness, understanding and knowledge among people of the Maldives about global environment," and "to initiate and carry out activities and projects at different levels in the Maldives for the protection of our delicate environment" (Bluepeace Maldives 2016). The 
organization has had global reach through media coverage, where it claims to represent the nation's environmentalist voice. It is also clearly situated within the transnationally recognizable category of the civil society NGO, whose severely limited budget and emphasis on public-private partnerships (Hussein interview 2011) trains its focus on infinitesimal interventions rather than large-scale structural interventions. Its staff consists of a network of volunteers of mostly urban and elite socioeconomic status. Some of its affiliates were closely linked to members of the presidential administration during the Nasheed years. The administration saw Bluepeace as an ally in the national fight against climate change and mobilization for carbon neutrality.

Bluepeace's director, Adil Hussein, would repeatedly critique the aspiration shared across the country for (both "d" and "D") development and comfortable urban living. His critiques made clear the complexity of a national policy to confront the local impacts of the climate crisis and, at the same time, challenge the planetary climate crisis through a collective Maldivian ecological resilience. A large billboard we passed on the dhony (or inter-island ferry) from the capital city of Malé5 out to Hulhumale, one of the country's new artificially built islands, showed happy people living in elegant luxury condominiums. Hussein remarked with displeasure that this was indicative of the larger consumerist impulse in the Maldives. But interviews with Maldivians I met in coffee shops and on the streets of Malé suggested that the worry about consumerism was a point of fracture between elites and people of lower socioeconomic status. Desires for development are about more than consumption among the citizenry: given that the Maldives draws on networks of highemissions, long-distance transport to import nearly all of its food, staple goods, and essential products, many saw the idea of becoming carbon-neutral as a threat to ordinary Maldivian livelihood.

The inter-island ferry (dhony) I took with Bluepeace staff to Hulhumale was a compelling setting for our discussion about the Maldivian populace's consumerism. Hussein and another volunteer were headed to Hulhumale, a newly dredged artificial island constructed to ease Malé's urban overpopulation. There, Bluepeace volunteers had located an unused stretch of beach and woods, where they were designing a mangrove ecosystem intended to offset the adjacent neighborhood's carbon dioxide emissions. This was meant, in turn, to contribute in a small way to the mission to render the entire country carbon-neutral.

According to Hussein, "they're spending massive amounts of money on projects renovating the islands, their harbors, schools and everything, but there's still influx" of population into Malé despite improvements to smaller outlying islands, "because everyone wants to be in the city." Why? "It's development. They run from their old sustainable lifestyles...The atolls don't know. They only want modern buildings, harbors, and stuff like that." Hussein's depiction of what he saw as the ignorant decision to urbanize here showed a curious inversion of conventional images of rural backwaters, whose migrants were paradoxically not enlightened enough to refuse modern urban growth. Anticipating that the Maldivian masses would not be interested in carbon neutrality, Hussein claimed, "our rhetoric is different from the reality. The reality is that we go around Malé in motorbikes, just for fun, burning the petrol."

The NGO officially endorses sea walls, the creation of new islands, and almost anything possible to maintain Maldivian habitability. Officially, the organization was aligned with the carbon neutrality push, and with the Maldivian government in approaching the nation as the unit of resilience. But Hussein also went offscript, asserting his personal politics by rescaling the unit of resilience away from the state. Resilience, he suggested, was about individuals and families, and their choices. And it should not mean the ability to stay on an island, but the ability to leave.

He explained his view like this: "I believe that islands are temporary places," Hussein told me, and our life should be more nomadic... You are a highly resilient person. You can move with your family anywhere. So what [we] need is [to] change our way of life. The way of our ol- older people...back to those days" (Hussein interview 2011). ${ }^{6}$ Here, Hussein hesitated on "ol- older people," improvising a narrative of resilience that highlighted the absurdity of assuming that political units must be preserved in order for human life and ecosystems to endure. Conjuring the idea of an indigenous island dweller located in the remote

\footnotetext{
${ }^{5}$ About one third of Maldivians reside in the capital city of Malé. People from outlying islands continually migrate to Malé, in one of the world's most centralized countries.

${ }^{6}$ I offer an earlier interpretation of this quote in Hirsch (2015).
} 
reaches of an unspecified past, he imagined an idealized figure, the resilient human. This individual, the rescaled unit of resilience-as opposed to the world, the state, the municipality, or any other possible unit, was imagined as a likely male household head ("You can move with your family anywhere"). The figure had no problem sacrificing routines and settling new islands. Hussein's image fits closely with the critique that transnational anxieties about "climate refugees" overlook long histories of mobility and adaptive refugeseeking among many of the world's island dwellers (Farbotko and Lazrus 2012). Distinguishing between elitist environmentalism and what he saw as the low- and working-class obsession with aspirational modernization and industrial development, Hussein was intervening in what he saw as development's unquestioned dominance as a priority. His assessment of "d" development was an astonishing indictment: "Development," he argued, "is the destruction of our culture."

Yet like many Andeans who chose to work for mines, resilience for many non-elite Maldivians meant household economic growth, which remained the most compelling antidote to scarcity. Some non-elites viewed imminent island vulnerability to rising seas as a problem. But the proportion of Maldivians that have had to move due to the encroaching ocean has so far remained low, and those islands have tended to be situated at the margins of national life. In my ethnography, I found concerns with everyday necessities, worries about the state's disinvestment, and interests in economic aspiration and tapping into the national aggregate wealth that had so far benefited so few, to be significantly more pressing for most individuals with whom I spoke (i.e. Jalal interview 2011). Indeed, upon my arrival in Malé, it was an early ethnographic surprise to learn that this was not a national public collectively transfixed in horror at the prospect of their entire nation disappearing, as international media outlets would have their audiences believe.

If resilience is a locally grounded theory of human permanence, imagining it requires the reconsideration of spatial and temporal scales of endurance. Resilience in Hussein's unofficial Maldivian image of degrowth and postdevelopment life was an active politics in the making that reframed the adaptation of a system needed in order for it to remain itself as a goal achievable at the level of a person, a family, or even a people, and which in Hussein's view did not require the endurance of fixed settlements, collectives, or states. According to this perspective, the political unit, qua unit, was ethically inconsequential in the long term, and compared to the nomadic island way of life, historically evanescent.

The politics surrounding definitions of this unit of resilience are fundamentally intertwined with conceptual conflicts between conventional and alternate politics, impacting the shifting comparative importance of individual, community, and nation. In February 2012, climate crisis was overtaken by political crisis in the Maldives when internal tensions came to a head. Nasheed resigned in the wake of mass protest and mounting political violence in murky circumstances that he called a "coup." Though the protest was due in significant part to mobilization by his political foes, many Maldivians attributed his administration's fragile hold on power to his inattention to ordinary development priorities, which seemed to threaten the country's recent success in graduating from "least developed country" status (Shahid interview 2011). While Nasheed did not dramatically alter food provision policies or change other systems in place to ensure local development in the Maldives, his rhetoric was consequential for his own fragile hold on political leadership. The administration's gamble was to make an official push to display exemplary Maldivian degrowth in the face of climate vulnerability by becoming completely carbon-neutral by 2020, transforming itself into the miners' canary that could also "point the way out of the mine." This clashed with Hussein's image of islands as temporary places in terms of human life stories. But it also clashed with priority of daily survival, for which Nasheed's high-publicity bids generated substantial worry among the non-environmentalist Maldivian population, who prioritized households and families as the key units of resilience. The president's ouster and imprisonment highlight the extremely high stakes of contested units of resilience on a climate change frontier.

\section{Conclusion}

These two sites illuminate the contradictory forces that are exerted by often-uncomfortable intersections of degrowth, development interventions, and disinvestment on the actors and groups who are forging grounded theories of resilience in the face of diverse forms of vulnerability. Climate change can be a devastating reminder that nothing lasts forever. But climate change also offers a flash of urgency for many 
communities, inspiring them to imagine and shape local visions of how life will go on. In Peru, the Maldives, and much of the so-called "underdeveloped" world, D/degrowth can come into uneasy tension with priorities that some say are best secured by economic expansion, by augmenting development. Understanding those tensions, making compromises within them, and imagining new kinds of futures, together entails political decisions that engage the different units of resilience in an effort to define their role in making sense of a planetary problem.

The Maldives shows us a site in which the state became the status quo unit of resilience. Bluepeace director Hussein rejected this unit as he spoke about his personal views and narrated a distinct vision of the future. In Peru's Colca Valley, it was not the state, but the state's absence and its move away from Development, that most immediately motivated institutions to end their projects in the region. There, the recent local history of development shows the unit of resilience shifting back and forth from region, to community, to family, and even to the individual, a figure whose entrepreneurship and labor flexibility was seen by some household heads to be the single pathway to getting by, given their circumstances. In both places, many non-elites decoupled economic resilience from ecological resilience in their own lives so that they could adapt to the diverse limits to growth.

Together, Peru and the Maldives show us the often-difficult negotiations involved in imagining permanence. They also suggest the possibilities of resilience as a resource for articulating priorities in the defining moments when development's limits come to matter in daily life. Finally, they make clear that any collective path forward organized by growing less and accommodating the biosphere's carrying capacity must account for the political significance of resilience and the importance of economic justice. In organizing a framework for imagining permanence, resilience occasions new engagements with the scale at which people with political and ethical power make high-stakes choices as they reconfigure political subjects and map out futures.

\section{References}

Alexander, D.E. 2013. Resilience and disaster risk reduction: an etymological journey. Natural Hazards and Earth System Sciences 13: 2707-2716.

Altamirano Rua, T. 2014. Refugiados ambientales: cambio climático y migración forzada. Lima: Fondo Editorial-Pontificia UniversidaBerg

d Católica del Perú.

Anderson, R. 2015. Sustainability, ideology, and the politics of development in Cabo Pulmo, Baja California Sur, Mexico. Journal of Political Ecology 22: 239-254.

Berglund, E. 2017. Steering clear of politics: local virtues in Helsinki's design activism. Journal of Political Ecology 24: 566-581.

Bluepeace Maldives. 2016. About us - objectives. http://www.bluepeacemaldives.org/aboutbluepeace.htm [accessed 30 January 2016.]

Bolin, I. 2009. The glaciers of the Andes are melting: indigenous and anthropological knowledge merge in restoring water resources. In Crate, S.A. and M. Nuttall (eds.) Anthropology and climate change: from encounters to actions. Walnut Creek, USA: Left Coast Press. Pp. 228-239.

Boonstra, W.J. and S. Joosse. 2013. How degrowth can develop from within capitalism. Environmental Values 22(2): 171-189.

Brown, W. 2015. Undoing the demos: neoliberalism's stealth revolution. New York: Zone.

Bury, J. and A. Kolff. 2002. Livelihoods, mining, and peasant protests in the Peruvian Andes. Journal of Latin American Geography 1:3-19.

Carey, M. 2014. In the shadow of melting glaciers: climate change and Andean society. Oxford: Oxford University Press.

De la Cadena, M. 2015. Earth beings: ecologies of practice across Andean worlds. Durham: Duke University Press. 
Demaría, F., F. Schneider, F. Sekulova and J. Martinez-Alier. 2013. What is degrowth? From an activist slogan to a social movement. Environmental Values 22(2): 191-215.

DeVore, J. 2017. Trees and springs as social property: A perspective on degrowth and redistributive democracy from a Brazilian squatter community. Journal of Political Ecology 24: 644-666.

Elyachar, J. 2005. Markets of dispossession: NGOs, economic development and the State in Cairo. Durham: Duke University Press.

Farbotko, C. and H. Lazrus. 2012. The first climate refugees? Contesting global narratives of climate change in Tuvalu. Global Environmental Change 22(2): 382-390.

Fuentes, J. 2011. Análasis del microcrédito en el ambito rural (Colca). Chivay: Caja Nuestra Gente. [CNG Archives]

Galison, P. 2004. Einstein's clocks, Poincaré's maps: empires of time. New York: Norton.

Gelles, P. H. 2000. Water and power in highland Peru: the cultural politics of irrigation. New Brunswick: Rutgers University Press.

Gilmore, B. 2013. The world is yours: "Degrowth", racial inequality and sustainability. Sustainability 5: 1282-1303.

Hirsch, E. 2015. "It won't be any good to have democracy if we don't have a country": climate change and the politics of synecdoche in the Maldives. Global Environmental Change 35: 190-198.

Hirsch, E. 2016. Mediating indigeneity: public space and the making of political identity in Andean Peru. PoLAR: Political and Legal Anthropology Review. 39(1): 95-109.

Kosoy, N., P.G. Brown, K. Bosselmann, A. Duraiappah, B. Mackey, J. Martinez-Alier, D. Rogers and R. Thomson. 2012. Pillars for a flourishing Earth: planetary boundaries, economic growth delusion and green economy. Current Opinion in Environmental Sustainability 4: 74-79.

Latouche, S. 2009. Farewell to growth. Malden: Polity Press.

Llosa Larrabure, J., E. Pajares Garay, and O. Toro Quinto (eds). 2009. Cambio climático, crisis del agua y adaptación en las montañas andinas: reflexión, denuncio y propuesta desde los Andes. Lima, Peru: Desco/Red Ambiental Peruana.

Lockyer, J. 2017. Community, commons, and degrowth at Dancing Rabbit Ecovillage. Journal of Political Ecology 24: 519-542.

McGuirk, E. 2017. Timebanking in New Zealand as a prefigurative strategy within the wider degrowth movement. Journal of Political Ecology 24: 595-609.

Mitlin, D., S. Hickey, and A.J. Bebbington. 2007. Reclaiming development? NGOs and the challenge of alternatives. World Development 35 (10): 1699-1720. draft

Mosse, D. 2013. The anthropology of international development. Annual Review of Anthropology. 42: 227246.

Murra, J.V. 1972. The 'vertical control' of a maximum of ecological levels in the economy of Andean societies. In Iñigo Ortiz de Zúñiga (1967-1972 [1562]), Vista de la provincia de León de Huánuco en 1562. Huánuco, Peru: Universidad Nacional Hermilio Valdizán. 2: 427-476.

Nixon, R. 2011. Slow violence and the environmentalism of the poor. Cambridge: Harvard University Press.

Paulson, S. 2014. Political ecology. In D'Alisa, G., F. Demaria and G. Kallis (eds.) Degrowth: a vocabulary for a new era. New York: Routledge. Pp. 45-49.

Paulson, S. 2017. Degrowth: culture, power and change. Journal of Political Ecology 24: 425-448.

Peet, R., P. Robbins, and M.J. Watts (eds.). 2011. Global political ecology. London: Routledge. Scribd

Postigo, J. 2014. Perception and resilience of Andean populations facing climate change. Journal of Ethnobiology 34(3): 383-400.

Povinelli, E.A. 2011. Economies of abandonment: social belonging and endurance in late liberalism. Durham, USA: Duke University Press.

Roy, A. 2010. Poverty capital: microfinance and the making of development. London: Routledge. 
Rudnikyj, D. and A. Schwittay. 2014. Afterlives of development. Political and Legal Anthropology Review 37(1): 3-9.

Schuster, C. 2015. Social collateral: women and microfinance in Paraguay's smuggling economy. Berkeley: University of California Press.

Verma, R. 2017. Gross National Happiness in Bhutan: meaning, measure and degrowth in a living development alternative. Journal of Political Ecology 24: 476-490.

Warner, K., T. Afifi, K. Henry, T. Rawe, C. Smith and A. de Sherbinin. 2012. Where the rain falls: climate change, food and livelihood security, and migration. Global Policy Report of the Where the Rain Falls Project. Paris: CARE France/United Nations University.

Watts, M.J. and R. Peet. 2004. Liberating political ecology. In R. Peet and M.J. Watts (eds.) Liberation ecologies: environment, development, social movements. $2^{\text {nd }}$ edition. New York: Routledge. Pp. 3-47.

Whitehead, M. 2013. Degrowth or regrowth? Environmental Values 22(2): 141-145. 